\title{
Influence of Micronutrients and Organics on Growth and Yield of Capsicum cv. Solan Bharpur under Shade Net Condition
}

\author{
M. Raja Naik* \\ College of Horticulture (Dr. YSRHU), Anantharajupeta - 516 105, Andhra Pradesh, India \\ *Corresponding author
}

\section{A B S T R A C T}

\begin{tabular}{|c|c|}
\hline & \multirow{4}{*}{$\begin{array}{l}\text { The present investigation was conducted at Horticultural Research Station, } \\
\text { Anantharajupeta, Dr. Y.S.R Horticultural University, Andhra Pradesh during 2014-2015. } \\
\text { The trail was carried out in capsicum cv. Solan Bharpur consisting of } 11 \text { treatments, } \\
\text { replicated thrice with Randomized Block Design. The results revealed that, capsicum } \\
\text { plants applied with } 10 \mathrm{t} / \mathrm{ha} \text { of well rotten farm yard manure }\left(\mathrm{T}_{10}\right) \text { recorded significantly } \\
\text { taller plant }(87.30 \mathrm{~cm}), \text { number of leaves }(163.77) \text {, stem girth }(4.85 \mathrm{~cm}) \text {, leaf length }(19.04 \\
\mathrm{cm}) \text {, leaf width }(11.33 \mathrm{~cm}) \text {. However, higher number of fruits }(25.66) \text {, fruit length }(8.83 \\
\mathrm{cm}) \text {, fresh fruit weight }(58.83 \mathrm{~g}) \text {, weight of } 10 \text { fruits }(663.72 \mathrm{~g}) \text {, yield }(16.32 \mathrm{t} / \mathrm{ha}) \text {, pericarp } \\
\text { thickness at the blossom end }(1.33 \mathrm{~cm}) \text {, number of seeds per fruit }(140.05) \text {, dry weight of } \\
100 \text { seeds }(0.71 \mathrm{~g}) \text {, fruit diameter }(18.25 \mathrm{~cm}) \text { and pericarp thickness at the centre of the } \\
\text { fruit }(0.81 \mathrm{~cm}) \text { were registered with the application of vermicompost }(2.50 \mathrm{t} / \mathrm{ha})\left(\mathrm{T}_{9}\right) \text {. }\end{array}$} \\
\hline & \\
\hline & \\
\hline & \\
\hline
\end{tabular}

\section{Introduction}

Sweet pepper (Capsicum annum L.) is a member of family solanaceae and genus capsicum. Tropical South America, especially Brazil is thought to be the original home of pepper. It is now widely cultivated in Central and South America, Peru, Bolivia, Costa Rica, Mexico, in almost all the European countries, Hong Kong and India. In India it is cultivated commercially in Tamil Nadu, Karnataka and Himachal Pradesh and in some parts of Uttar Pradesh.

Organic fertilizer is the key to improve the sustainability of agricultural farming system and soil productivity. It has been proved that indiscriminate use of inorganic fertilizers results in decrease in soil fertility and increase in soil acidity with depletion of organic humus content in addition to poor crop quality. Use of organic manures to meet the nutrient requirements of crop would be an inevitable practice in the years to come for sustainable agriculture since organic manures not only improve the soil physical, chemical and biological properties (Heitkamp et al., 2011) but also improves the moisture holding capacity of soil, thus resulting in enhanced crop productivity along with better quality of crop produce (Premsekhar and Rajashree, 2009). Micronutrients play vital roles in the growth and development of plants, due to their stimulatory and catalytic effects on metabolic 
processes and ultimately on flower yield (Lahijie, 2012) and quality (Khosa et al., 2011). The growth parameters like plant height and number of branches plant ${ }^{-1}$ was found maximum with combined application of vermicompost, FYM and urea at 50 per cent level. The yield attributes including fruit yield was found maximum with nitrogen received from vermicompost and urea at 50 per cent level. Improvement in qualitative aspects was increased with the application of neem cake compared to other inorganic sources (Pariari and Khan, 2013).

Vermicompost is a rich source of vitamins, hormones, enzymes, macro and micronutrients which when applied to plants help in efficient growth (Prabhakaran, 2005). The growth rate is fast due to increased uptake of macro and micronutrients present in the vermicompost, which results in increased shoot length and number of leaves in vermicompost applied plants. Vermicompost being rich in NPK and other nutrients can be used as a substitute for chemical fertilizer (Jeyabal and Kuppuswamy, 2001).

Application of micronutrients viz., zinc, boron, magnesium and organics viz., vermicompost and FYM bring profound changes in various metabolic processes within the plant system thereby influence the yield considerably. In recent years, the roles of these micronutrients are gaining more importance particularly in capsicum to boost not only the productivity but also to improve the quality. Hence, an investigation on the effect of micronutrients and organics on growth and quality of capsicum under shade net conditions was initiated.

\section{Materials and Methods}

A field experiment entitled "Influence of micronutrients and organics on growth and yield of capsicum cv. Solan Bharpur under shade net condition" was conducted during rabi season of 2014-15. The experiment was carried out at Horticultural Research Station, Anantharahjupeta, Y.S.R Kadapa Dist. Andhra Pradesh. The experimental field was laid out in Randomized Block Design with 11 treatments with three replications. The details of experimental treatment plan employed in the present investigation was carried out as follows: $\mathrm{T}_{1}-\mathrm{ZnSO}_{4}(25 \mathrm{~kg} / \mathrm{ha}), \mathrm{T}_{2}-\mathrm{ZnSO}_{4}$ (0.2\%), $\quad \mathrm{T}_{3}$-Borax $(10 \mathrm{~kg} / \mathrm{ha}), \quad \mathrm{T}_{4}$-Borax (0.2\%), $\quad \mathrm{T}_{5}-\mathrm{MgSO}_{4} \quad(10 \mathrm{~kg} / \mathrm{ha}), \quad \mathrm{T}_{6}-\mathrm{MgSO}_{4}$ $(0.2 \%), \quad \mathrm{T}_{7}-\mathrm{FeSO}_{4} \quad(10 \mathrm{~kg} / \mathrm{ha}), \quad \mathrm{T}_{8}-\mathrm{FeSO}_{4}$ (0.2\%), $\mathrm{T}_{9}$-Vermicompost $(2.50 \mathrm{t} / \mathrm{ha}), \mathrm{T}_{10^{-}}$ FYM (10 t/ha) and $\mathrm{T}_{11}$-Control (No application of any nutrients).

After ploughing and digging, the land was brought to fine tilth under shade net house. All weeds were completely removed from the field. All the stubbles of previous crop were removed from the field and burnt. The trial was conducted in red loam soil with a spacing of $60 \times 60 \mathrm{~cm}$ and planting was done with 45 days old healthy seedlings during November, 2014. The experimental plots were of size $2.50 \times 2.50 \mathrm{~m}$ and each plot consisted of size ridges with $20 \mathrm{~cm}$ spacing. The soil of the experimental field was red loam in texture with $\mathrm{pH}$ 7. 2. Necessary plant protection measures were followed to prevent pest and disease incidence. Well decomposed farmyard manure@10 t ha ${ }^{-1}$ and vermicompost @ 2.50 $\mathrm{t} \mathrm{ha}^{-1}$ was applied uniformly as per the treatment and mixed well. The manures were incorporated in the respective plots 20 days before planting when applied as basal. Recommended micronutrients viz., Zn, Bo, $\mathrm{Mg}$ and $\mathrm{Fe}$ are applied as basal dose as per treatment and foliar feeding for two times once at fruit setting and again at fruit development stage. At initial stage of growth, spinosod @ $0.2 \mathrm{ml} \mathrm{l}^{-1}$ was sprayed to manage sucking pests and Spodoptera litura, while no disease incidence was noticed during the investigation period. For recording 
observations, five plants were selected per each plot at random and were labelled properly by indicating treatments. The data were analysed using the procedure outlined by Panse and Sukhatme (1985).

\section{Results and Discussion}

The perusal of data presented in Table 1 clearly indicated that plant height $(87.30 \mathrm{~cm})$, number of leaves (163.77), stem girth (4.85 $\mathrm{cm})$, leaf length $(19.04 \mathrm{~cm})$ and leaf width $(11.33 \mathrm{~cm})$ recorded was maximum with the application of FYM @ $10 \mathrm{t} \mathrm{ha}^{-1}$. Number of branches per plant was not significantly influenced by treatments. Similar types of results have also reported by Sahoo et al., (2017) in sweet pepper and Reddy et al., (2017) in chilli. The good plant growth, number of leaves and higher leaf length and width may be due to application of FYM which might have acted as a source of additional nutrients and moisture supply. The earlier study made by Patil et al., (2014),
Singh et al., (2014), Omogoya and Adewale (2015) also reported application of FYM and other organic manures significantly influence the growth and development of capsicum.

Data furnished in Table 2 and 3 shows that higher number of fruits (25.66), fruit length $(8.83 \mathrm{~cm})$, fruit diameter $(18.25 \mathrm{~cm})$, fresh fruit weight $(58.83 \mathrm{~g})$, weight of 10 fruits $(663.72 \mathrm{~g})$, yield $(16.32 \mathrm{t} / \mathrm{ha})$, pericarp thickness at the blossom end $(1.33 \mathrm{~cm})$, number of seeds per fruit (140.05), dry weight of 100 seeds $(0.713 \mathrm{~g})$ and pericarp thickness at the centre of the fruit $(0.81 \mathrm{~cm})$ were recorded with the application of vermicompost (2.50 t/ha).Vermicompost used in this treatment is known to enhance microbial activity, which may have improved availability of macro and micro nutrients to the plants. It also acts as a chelating agent and regulates availability of metabolic micro nutrients to plants and, thus helps increase yield attributing traits by providing nutrients in their available form.

Table.1 Influence of micronutrients and organics on biometric attributes of capsicum cv. Solan Bharpur under shade net condition

\begin{tabular}{|c|c|c|c|c|c|c|}
\hline Treatments & $\begin{array}{l}\text { Plant } \\
\text { height } \\
\text { (cm) }\end{array}$ & $\begin{array}{c}\text { Number of } \\
\text { leaves per } \\
\text { plant }\end{array}$ & $\begin{array}{l}\text { Number of } \\
\text { branches } \\
\text { per plant }\end{array}$ & $\begin{array}{l}\text { Stem girth } \\
\text { (cm) }\end{array}$ & $\begin{array}{l}\text { Leaf length } \\
\text { (cm) }\end{array}$ & $\begin{array}{l}\text { Leaf width } \\
\text { (cm) }\end{array}$ \\
\hline $\mathrm{T}_{1}$ & 63.30 & 127.44 & 11.77 & 4.04 & 17.28 & 7.77 \\
\hline$\overline{T_{2}}$ & 62.40 & 141.22 & 10.44 & 4.36 & 17.26 & 8.17 \\
\hline $\mathbf{T}_{3}$ & 66.33 & 127.88 & 10.11 & 4.07 & 17.33 & 7.93 \\
\hline$T_{4}$ & 67.40 & 133.44 & 10.00 & 4.03 & 16.94 & 8.01 \\
\hline $\mathbf{T}_{5}$ & 68.28 & 128.11 & 11.55 & 3.96 & 16.30 & 8.53 \\
\hline$\overline{T_{6}}$ & 68.95 & 123.77 & 11.00 & 4.04 & 17.37 & 8.26 \\
\hline$T_{7}$ & 61.38 & 142.77 & 9.88 & 4.06 & 17.01 & 8.03 \\
\hline$T_{8}$ & 57.07 & 150.22 & 11.22 & 3.95 & 17.91 & 8.32 \\
\hline $\mathbf{T}_{9}$ & 71.12 & 159.77 & 13.00 & 4.44 & 18.00 & 8.88 \\
\hline$T_{10}$ & 87.30 & 163.77 & 14.00 & 4.85 & 19.04 & 11.33 \\
\hline $\mathbf{T}_{11}$ & 56.32 & 122.88 & 9.77 & 3.46 & 15.33 & 7.25 \\
\hline $\mathrm{CD}(P=0.05)$ & 11.87 & 24.56 & N.S & 0.47 & 1.72 & 0.88 \\
\hline S.Em. \pm & 3.99 & 8.27 & 1.05 & 0.16 & 0.58 & 0.29 \\
\hline C.V\% & 10.43 & 10.35 & 16.43 & 6.65 & 5.83 & 6.11 \\
\hline
\end{tabular}


Table.2 Influence of micronutrients and organics on fruit traits of capsicum cv. Solan Bharpur under shade net condition

\begin{tabular}{|c|c|c|c|c|c|c|}
\hline Treatments & $\begin{array}{l}\text { Number } \\
\text { of fruits } \\
\text { per plant }\end{array}$ & $\begin{array}{l}\text { Fruit } \\
\text { length } \\
\text { (cm) }\end{array}$ & $\begin{array}{c}\text { Fruit } \\
\text { breadth } \\
\text { (cm) }\end{array}$ & $\begin{array}{c}\text { Fruit } \\
\text { diameter } \\
(\mathrm{cm})\end{array}$ & $\begin{array}{c}\text { Fresh } \\
\text { fruit } \\
\text { weight (g) }\end{array}$ & $\begin{array}{l}\text { Weight of } \\
10 \text { fruits } \\
\text { (g) }\end{array}$ \\
\hline $\mathbf{T}_{1}$ & 17.44 & 6.91 & 5.32 & 12.29 & 46.55 & 540.63 \\
\hline $\mathbf{T}_{2}$ & 20.88 & 6.55 & 5.40 & 13.00 & 55.53 & 624.77 \\
\hline $\mathbf{T}_{3}$ & 18.88 & 7.56 & 5.15 & 11.00 & 52.45 & 616.27 \\
\hline$\overline{T_{4}}$ & 17.88 & 7.18 & 5.36 & 14.63 & 49.83 & 561.12 \\
\hline$T_{5}$ & 20.77 & 6.32 & 5.11 & 15.55 & 40.38 & 464.21 \\
\hline$T_{6}$ & 16.33 & 6.65 & 5.53 & 11.35 & 51.11 & 533.33 \\
\hline$T_{7}$ & 17.00 & 7.05 & 5.66 & 10.00 & 50.84 & 597.54 \\
\hline$T_{8}$ & 15.77 & 6.78 & 5.18 & 9.33 & 44.33 & 548.14 \\
\hline$T_{9}$ & 25.66 & 8.83 & 5.77 & 18.25 & 58.83 & 663.72 \\
\hline$T_{10}$ & 15.77 & 7.14 & 5.38 & 16.00 & 49.94 & 581.90 \\
\hline $\mathbf{T}_{11}$ & 14.22 & 6.04 & 4.86 & 6.78 & 35.50 & 440.37 \\
\hline $\mathrm{CD}(P=0.05)$ & 2.25 & 0.93 & NS & 1.45 & 8.97 & 45.32 \\
\hline S.Em. \pm & 0.76 & 0.31 & 0.25 & 0.48 & 3.02 & 15.25 \\
\hline C.V\% & 7.22 & 7.76 & 8.08 & 6.72 & 10.74 & 4.71 \\
\hline
\end{tabular}

Table.3 Influence of micronutrients and organics on fruit and seed parameters of capsicum cv. Solan Bharpur under shade net condition

\begin{tabular}{|c|c|c|c|c|c|c|}
\hline Treatments & $\begin{array}{l}\text { Yield } \\
\text { (t/ha) }\end{array}$ & $\begin{array}{l}\text { Pericarp } \\
\text { thickness } \\
\text { at the } \\
\text { blossom } \\
\text { end (cm) }\end{array}$ & $\begin{array}{l}\text { Pericarp } \\
\text { thickness at } \\
\text { the centre } \\
\text { of the fruit } \\
\text { (cm) }\end{array}$ & $\begin{array}{l}\text { Number } \\
\text { of seeds } \\
\text { per fruit }\end{array}$ & $\begin{array}{c}\text { Seed } \\
\text { weight/ } \\
\text { fruit (g) }\end{array}$ & $\begin{array}{c}\text { Dry } \\
\text { weight of } \\
100 \text { seeds } \\
\text { (g) }\end{array}$ \\
\hline $\mathrm{T}_{1}$ & 15.14 & 1.26 & 0.71 & 135.21 & 1.190 & 0.700 \\
\hline $\mathbf{T}_{2}$ & 16.13 & 1.27 & 0.68 & 127.74 & 1.220 & 0.697 \\
\hline $\mathbf{T}_{3}$ & 15.12 & 1.24 & 0.59 & 122.80 & 1.160 & 0.690 \\
\hline $\mathbf{T}_{4}$ & 14.53 & 1.21 & 0.62 & 115.01 & 1.140 & 0.707 \\
\hline$T_{5}$ & 14.28 & 1.23 & 0.64 & 133.89 & 1.223 & 0.690 \\
\hline$T_{6}$ & 15.50 & 1.26 & 0.70 & 120.23 & 1.203 & 0.677 \\
\hline$T_{7}$ & 14.85 & 1.29 & 0.66 & 124.84 & 1.177 & 0.643 \\
\hline$T_{8}$ & 14.60 & 1.24 & 0.63 & 130.98 & 1.120 & 0.637 \\
\hline$T_{9}$ & 16.32 & 1.33 & 0.81 & 140.05 & 1.300 & 0.713 \\
\hline $\mathbf{T}_{10}$ & 14.69 & 1.16 & 0.49 & 113.74 & 1.210 & 0.663 \\
\hline $\mathbf{T}_{11}$ & 12.88 & 1.13 & 0.48 & 104.62 & 1.160 & 0.627 \\
\hline $\mathrm{CD}(P=0.05)$ & 0.38 & 0.08 & 0.11 & 7.61 & N.S & 0.046 \\
\hline S.Em. \pm & 0.12 & 0.02 & 0.03 & 2.56 & 0.06 & 0.015 \\
\hline C.V\% & 1.48 & 3.78 & 10.14 & 3.56 & 8.65 & 3.950 \\
\hline
\end{tabular}


Besides, vermicompost also contains significant quantities of nutrients, a large amount of beneficial microbial populations and biologically active metabolites particularly gibberellins, cytokinins, auxins and vitamins (Bhavalkar, 1991) all of which have a beneficial effect on photosynthesis and translocation.

Results of the present findings are in agreement with findings of several earlier workers viz. Jeevansab (2000), Salas and Ramirez (2001), Basavaraja et al., (2003) and Ganiger et al., (2012) in capsicum (bell pepper).

Organic manures increases the availability of nutrients, especially protein synthesis further it was suggested that significantly increase in number of fruits and fresh, dry weight of fruit weight might have accelerated the mobility of photosynthetic from source to the sink which was influenced by the growth hormones which released from Vermicompost, the organic sources. Similar findings were reported by Dileep and Sasikala (2009), Deshpande et al., (2010), Singh et al., (2014), Jayanti et al., (2014), Mudiganti et al., (2015) in chilli and Jamir et al., (2017) in sweet pepper. Congenial environment prevail under shade net house might also favours for good growth and yield of capsicum cv. Solan Bharpur.

Application of nutrients like Vermicompost and FYM has a significant and vital effect on growth, yield and quality attributes of capsicum. The supply of various plant nutrients at an optimum level sustains the desired crop productivity by optimizing the benefit from all sources in an integrated manner. The inference drawn from the present investigation clearly stated that organics are effective alternatives as a source of macro- and micronutrients and have a potential to improve yield, and thus avoid costly chemical fertilizers. The bio-organic technology is based on eco-biotechnological approaches utilizing the bio-transformation of energy rich and complex organic substances into bio-stabilized composed products.

\section{References}

Basavaraja, N., Nandi, V.R. and Jhoglikar, P. 2003. Protected cultivation of capsicum and bhendi. Proceedings of All India seminar on potential and prospects for protective cultivation, Institute of Engineers, Ahmednagar, December 1213, 2003, pp.197-199.

Bhavalkar, V.S. 1991. Vermiculture biotechnology for LEISA. Seminar on low external input sustainable agriculture, Amsterdam. The Netherlands. pp. 1-6.

Deshpande, R. P., Soniya, T., Deshmukh, A. and Deshmukh, S. 2010. Effect of organic and inorganic manures on growth and yield of chilli. Int. J. Forestry and Crop Imp., 1(2): 146-148.

Dileep, S. N. and Sasikala 2009. Studies on the effect of different organic and inorganic fertilizers on growth, fruit characters, yield and quality of chilli (Capsicum annuum L.) cv.K-1. Intnl. J. of Agri. Sciences, 5(1): 229-232.

Ganiger, V.M., Mathad, J.C., Madalageri, M.B., Babalad, H.B. and Bhuvaneswari, G. 2012. Effect of organics and inorganics on yield parameters in bell pepper under open condition. J. Hort. Sci. 7 (2): 156160.

Heitkamp, F., Raupp, J. and Ludwig, B. 2011. Soil organic matter pools and crop yields as affected by the rate of farmyard manure and use of biodynamic preparations in a sandy soil. Organic Agriculture. 1: 11-124.

Jamir, T., Rajwade, V.B., Prasad, V.M. and Lyngdoh, C. 2017. Effect of organic manures and chemical fertilizers on growth and yield of sweet pepper (Capsicum annuum L.) Hybrid Indam Bharath in shade net condition. Int.J.Curr.Microbiol.App.Sci. 6(8): 10101019.

Jayanthi, L., Sekar, J., Ameer Basha, S. and Parthasarathi, K. 2014. Influence of vermifertilizer on soil quality, yield and 
quality of chilli (Capsicum annuum). International Inter disciplinary Research Journal. 4: 204-217.

Jeevansab, 2000. Effect of nutrient sources on growth, yield and quality of capsicum grown under different environments. M. Sc (Agri.) Thesis, Univ. Agri. Sci. Dharwad, Karnataka, India.

Jeyabal, A. and Kuppuswamy, G. 2001. Recycling of organic wastes for the production of vermicompost and its response in rice-legume cropping system and soil fertility. European J. Agronomy. 15(3): 153- 170.

Khosa, S. S., Younis, A., Rayit, A., Yasmeen, S. and Riaz, A. 2011. Effect of foliar application of macro and micro nutrients on growth and flowering of Gerbera jamesonii L. Amer. Euras. J. Agric.Environ. Sci.11: 736-757.

Lahijie, M. F. 2012. Application of micronutrients $\mathrm{FeSO}_{4}$ and $\mathrm{ZnSO}_{4}$ on the growth and development of gladiolus variety "Oscar". Int. J. Agric. Crop Sci., 4:718-720.

Mudiganti, R. K. R., Sathish, K. M. and Neema, K.J. 2015. Comparative yield analysis of chilli (Capsicum annuum L.) by application of vermicompost and panchagavya. Journal of Chemical and Pharmaceutical Research, 7(9): 319-323.

Omogoya and Adewale, M. 2015. Efficacy of NPK and cow dung combinations on performance of chilli pepper (Capsicum annum L.) and their influence on soil properties. IOSR Journal of Agriculture and Veterinary Science, 8(7): 31-35.

Panse, V.G. and Sukhatme, P.V. 1985. Statistical methods for agricultural workers, ICAR, New Delhi. 97-164.
Pariari, A. and khan, S. 2013. Integrated nutrient management of chilli (Capsicum annuum L.) in Gangetic alluvial plains. $J$. Crop and Weed. 9(2): 128-130.

Patil, I. D., Babalad, H.B. and Patil, R.K. 2014. Effect of organic nutrient and biological pest management practices on insect pest and disease dynamics in organic chilli production system. Int. J. of Recent Scient. Res., 5(9): 1524-1528.

Prabakaran, J. 2005. Biomass resources in vermicomposting, In: proceedings of the state level symposium on vermicomposting technology for rural development, (Ed. Jayakumar, E.), Madurai, Tamil Nadu, India. 27-40. (2005).

Premsekhar, M. and Rajashree, V. 2009. Influence of organic manures on growth, yield and quality of okra. AmericanEurasian J. Sustain. Agri. 3(1): 6-8.

Reddy, G.C., Venkatachalapathi, V., Reddy, G.P.D. and Hebbar, S.S. 2017. Study of different organic manure combination on growth and yield of chilli (Capsicum annuum L.). Plant Archives. 17 (1): 472474.

Sahoo, D., Sahoo, N.R. and Paramjita, D. 2017. Effect of bio-fertilisers on yield and quality of sweet pepper (Capsicum annuum cv. Grossum L.). J. Indian Soc. Coastal Agric. Res. 35(1): 15-20.

Salas, S. and Ramirez, C. 2001. A microbial bioassay to estimate nutrient availability of organic fertilizers: field calibration. Agronomia-Costaricense. 25: 11-23.

Singh, C. K. A., Suchit, J. and Devansu, J. 2014. Effect of organics on growth, yield and biochemical parameters of chilli (Capsicum annuum L.). IOSR J. Agri. Vet. Sci. 7(1): 2319-2372.

\section{How to cite this article:}

Raja Naik, M. 2018. Influence of Micronutrients and Organics on Growth and Yield of Capsicum cv. Solan Bharpur under Shade Net Condition. Int.J.Curr.Microbiol.App.Sci. 7(05): 2166-2171. doi: https://doi.org/10.20546/ijcmas.2018.705.252 